\title{
FIRE EFFECTS ON THE COMPOSITION OF A BIRD COMMUNITY IN AN AMAZONIAN SAVANNA (BRAZIL)
}

\author{
CINTRA, R. and SANAIOTTI, T. M. \\ Coordenação de Pesquisas em Ecologia, Instituto Nacional de Pesquisas da Amazônia \\ CP. 478, 69011-970, Manaus, AM, Brasil. \\ Correspondence to: Renato Cintra, Coordenação de Pesquisas em Ecologia, Instituto Nacional de Pesquisas da Amazônia, \\ CP. 478, CEP 69011-970, Manaus, AM, Brasil, e-mail: cintra@inpa.gov.br
}

Received September 15, 2003 - Accepted March 31, 2004 - Distributed November 30, 2005

(With 2 figures)

\begin{abstract}
The effects of fire on the composition of a bird community were investigated in an Amazonian savanna near Alter-do-Chão, Pará (Brazil). Mist-net captures and visual counts were used to assess species richness and bird abundance pre- and post-fire in an approximately 20 ha area. Visual counts along transects were used to survey birds in an approximately 2000 ha area in a nearby area. Results using the same method of ordination analysis (multidimensional scaling) showed significant effects of fire in the 20 ha and 2000 ha areas and strongly suggest direct effects on bird community composition. However, the effects were different at different spatial scales and/or in different years, indicating that the effects of fire vary spatially and/or temporally. Bird community composition pre-fire was significantly different from that found post-fire. Using multiple regression analysis it was found that the numbers of burned and unburned trees were not significantly related to either bird species richness or bird abundance. Two months after the fire, neither bird species richness nor bird abundance was significantly related to the number of flowering trees (Lafoensia pacari) or fruiting trees (Byrsonima crassifolia). Since fire is an annual event in Alter-doChão and is becoming frequent in the entire Amazon, bird community composition in affected areas could be constantly changing in time and space.
\end{abstract}

Keywords: fire, savanna, Amazonia, birds, community.

\section{RESUMO}

\section{Efeitos do fogo na composição da comunidade de aves em uma Savana amazônica brasileira}

Os efeitos do fogo na composição da comunidade de aves foram estudados em uma savanna perto de Alterdo-Chão, Pará, Brasil. Capturas usando redes ornitológicas e contagens visuais foram usadas para amostrar a riqueza de espécies e abundância de aves antes e depois do fogo em uma área de aproximadamente 20 ha. Contagens visuais ao longo de transectos foram usadas para amostrar aves numa área vizinha de aproximadamente 2000 ha. Resultados usando os mesmos métodos de análise de ordenação (escalonamento multidimensional) mostraram efeitos significativos do fogo nas áreas de 20 ha e 2000 ha, e sugerem fortemente que houve efeitos diretos do fogo na composição da comunidade de aves. Entretanto, os efeitos foram diferentes nas diferentes escalas espacias e ou anos, indicando que os efeitos do fogo variam espacialmente e ou temporalmente. A composição da comunidade de aves antes do fogo foi significativamente diferente daquela depois do fogo. Análise de regressão múltipla indica que o número de árvores queimadas e não queimadas não foi significativamente relacionado à riqueza de espécies ou à abundância de aves. Dois meses depois do fogo, nem a riqueza de espécies nem a abundância de aves foram significativamente relacionadas ao número de árvores florindo (Lafoensia pacari) e árvores frutificando (Byrsonima crassifolia). Como o fogo é um evento anual em Alter-do-Chão, e está se tornando frequente na Amazônia, as comunidades de aves em áreas afetadas pelo fogo podem estar mudando constantemente no tempo e no espaço.

Palavras-chave: fogo, savana, Amazônia, aves, comunidade. 


\section{INTRODUCTION}

In northern Brazil, Amazonian-type savannas (Huber, 1982) occur as "islands" of different sizes in a matrix dominated by Amazonian rainforest (Prance \& Lovejoy, 1985). Only two studies specifically on species composition and reproductive phenology of the bird community in Amazonian savanna have been made (Cintra, 1997; Sanaiotti \& Cintra, 2001). Most of the other studies on birds in these areas have either consisted of lists (Riker \& Chapman, 1891; Novaes, 1978; Moskovits et al., 1985; Stotz, 1997) or described distributional patterns (Silva et al., 1997). However, in the central plateau of Brazil many studies of savanna birds have been carried out (Negret \& Negret, 1981; Negret et al., 1984; Sick, 1985; Silva, 1995; Cavalcanti \& Pimentel, 1988; Cintra, 1988; Alves \& Cavalcanti, 1996; Cintra et al., 1990; Marini et al., 1997; Macedo, 2002).

Savannas, which are wintering sites for neotropical austral and nearctic migrant birds (Negret \& Negret, 1981), represent one quarter of the Brazilian land mass. However, only $1.2 \%$ of them are in protected areas (Myers et al., 2000).

In the environment surrounding the village of Alter-do-Chão, Pará, Brazil, fire occurs in the savanna annually at the end of the dry season (October-November), and in the Amazon region, induced fire incidence is increasing. In March 1998 more than one thousand fire sites were detected by satellite images in the State of Roraima, of which one quarter was burned, including $55.6 \%$ of the savanna and about $7.4 \%$ of the forests (Barbosa and Fearnside, 1999).

Since precipitation is higher in neighboring forested areas than it is in the Brazilian savannas, a debate exists on whether the latter are man-made or produced by local climate and soil conditions (see Coutinho, 1982). However, few studies have examined how the direct effects of abiotic factors (fire) or indirect effects of biotic factors (herbivory, predation, and competition) could influence plant and animal populations in this system.

Many tree species in the savanna not only survive annual fires but are probably adapted to them (Coutinho, 1982). Fire affects plant community dynamics by changing phenological behavior, with some shrub species flowering or fruiting two months after the normal period in years with fire (Sanaiotti \& Magnusson, 1995). Furthermore, annual fires may act as a stochastic process, resulting in local species extinction and facilitating colonization by invaders from heavily disturbed areas (Barlow et al., 2002; Cintra \& Sanaiotti, unpubl. data).

Although many studies are available about the effects of fire on Brazilian savanna vegetation, few focus on its consequences in animal communities. Furthermore, most studies have been conducted in savannas of the central plateau and southern Brazil (Araujo et al., 1996; Lousada et al., 1996; Cavalcanti \& Alves, 1997) as opposed to those conducted in Amazonian savannas (Magnusson et al., 2001).

In this study, we describe the effects of fire on the bird community at Alter-do-Chão. We investigated 1 ) whether there are significant changes in local bird species composition after fire; 2 ) how damage produced by fire (burned trees) is related to intact resources (unburned trees), and bird abundance and richness; 3 ) whether the variation in abundance of flowering and fruiting trees is related to bird abundance or species richness; and 4) whether the post-fire effects on bird community composition present the same pattern at small and large spatial scales and between years.

\section{MATERIALS AND METHODS}

The study was carried out during September 1996, November 1996, and February 1997. At a small scale $(\sim 20$ ha), birds were netted in an approximately $3 \mathrm{~km}$ long and 1-2 km wide savanna area located on a peninsula on the right margin of the Tapajós River near the village of Alter-doChão ( $\left.2^{\circ} 31^{\prime} \mathrm{S}, 55^{\circ} 00^{\prime} \mathrm{W}\right)$, Pará. At a larger scale, visual counts were carried out in five 3.75 ha plots in an approximately 2000 ha area adjacent to the peninsula. The whole savanna area in the land around the peninsula covers about 10,000 ha. The vegetation in the areas surveyed is dominated by a herbaceous stratum, principally of the grasses Paspalum carinatum and Trachypogon plumosus, interspersed with small patches of trees and shrubs. The soils in the area are mainly sandy and all areas surveyed were on such soils. Two thirds of the annual rainfall $($ mean $=2192 \mathrm{~mm})$ occurs between January and June (Miranda, 1993). 


\section{Bird Surveys}

We used two different survey methods for birds. At a 20 ha scale, we captured birds using mist nets. We surveyed them both visually and by their calls along four $500 \mathrm{~m}$ parallel transects, $500 \mathrm{~m}$ apart, two of which were in the burned area; the other two were located in an unburned site $1 \mathrm{~km}$ from the 20 ha area (see below). We have worked in this area for 12 years and we are familiar with all species present.

At a scale of 2000 ha, we surveyed birds along two parallel $250 \mathrm{~m}$ transects located $150 \mathrm{~m}$ apart in each of five plots distributed randomly within the area. The area between the transects in each plot was 3.75 ha.

The sample unit for mist netting was a $250 \mathrm{~m}$ net line composed of twenty $12 \mathrm{~m}$ long, and $2.3 \mathrm{~m}$ high mist nets of $36 \mathrm{~mm}$ nylon mesh, which were suspended in continuous straight lines, with the bottom of the lower shelf touching the ground. During five consecutive days we ran $250 \mathrm{~m}$ net lines (one line each day) that created a grid within an approximately 20 ha area. This procedure was carried out in September 1996 (about two months pre-fire) and was repeated in February 1997 (about two months post-fire) with the net line placed in exactly the same sites each time. The fire went through the area on November 10, 1996.

The study was conducted during an El Niño event and the local climate was less seasonally marked (in 1996-1997 the wet season was drier than usual). The nets were usually opened from 06:00 to 09:00 and from 16:00 to 18:00 h. We changed the net line position every day. Colored plastic bands and numbered aluminum rings (both furnished by CEMAVE-IBAMA, Center for Migrant Bird Study, Brasília) were attached to mist-netted birds after identification based on the work of either Meyer de Schauensee (1970) or Ridgely \& Tudor (1994a, 1994b),

Surveys along the $500 \mathrm{~m}$ transects located within the 20 ha area $\left(54^{\circ} 96^{\prime} 24^{\prime \prime} \mathrm{N}\right.$ and $2^{\circ} 48^{\prime} 89^{\prime}$ ' W) were conducted by RC, who is familiar with all species in the area. All birds seen or heard at observation points distributed at $50 \mathrm{~m}$ intervals along the transects were registered. To avoid counting the same bird twice, RC spent a maximum of 2 minutes counting all birds within a $10 \mathrm{~m}$ radius of each observation point.
Researchers use a variety of methods to survey birds, with correspondingly varied results (Gibbons et al., 1996). Conclusions may also be scale-specific (Peterson \& Parker, 1997). We opted for a survey method based on a larger spatial scale and carried out in different years to see whether our conclusions could be generalized, i.e., not restricted to the methods and scale of the first part of the study.

At the larger spatial scale, RC also did the bird surveys in five plots within the 2000 ha study area. The sampling units were 3.75 ha plots $(150 \times 250 \mathrm{~m})$, most of them about minimum $1 \mathrm{~km}$ apart. Respective geographical coordinates are as follows: plot $1,54^{\circ} 93^{\prime} 70^{\prime \prime} \mathrm{N}$ and $2^{\circ} 49^{\prime} 16^{\prime \prime} \mathrm{W}$; plot 2, $54^{\circ} 93^{\prime} 20^{\prime \prime} \mathrm{N}$ and $2^{\circ} 49^{\prime} 21^{\prime \prime} \mathrm{W}$; plot 3, $54^{\circ} 93^{\prime} 45^{\prime \prime} \mathrm{N}$ and $2^{\circ} 48^{\prime} 49^{\prime \prime} \mathrm{W}$; plot $4,54^{\circ} 93^{\prime}$ $27^{\prime \prime} \mathrm{N}$ and $2^{\circ} 49^{\prime} 84^{\prime \prime} \mathrm{W}$; plot $5,54^{\circ} 92^{\prime} 11^{\prime \prime} \mathrm{N}$ and $2^{\circ}$ $49^{\prime} 45^{\prime}$ ' W. Within each of the five plots, birds were counted, usually from 06:00 to 09:00 and from 16:00 to $18: 00 \mathrm{~h}$, every $50 \mathrm{~m}$ along two $250 \mathrm{~m}$ transects, with a 2 minutes maximum spent at each observation point, during which the observer recorded all birds seen and heard within a $10 \mathrm{~m}$ radius. One survey was conducted in November 1997 (pre-fire) when the vegetation in the plots was still intact; the other was carried out in January 1998 (two months post-fire) when the plots were completely burned.

\section{The effects of vegetation on birds}

To describe tree species composition, we surveyed 10 quadrats $(10 \times 10 \mathrm{~m})$ within the 20 ha area. In each, we measured trees with diameters $>5 \mathrm{~cm}$ at $30 \mathrm{~cm}$ above the ground. Relative frequency, relative dominance, and absolute frequency were calculated using the FITOPAC statistical pack version II (unpublished, G. Shepard, Universidade de Campinas, Brasil). Samples of all tree species are deposited at the INPA herbarium in Manaus and have been identified by specialists.

In this study we investigated whether the effects of fire on variation in abundance of natural resources available for perching (unburned and burned trees) and for feeding (flowering and fruiting trees) would ultimately affect local bird species richness (the total number of bird species recorded) and abundance (the total number of individuals recorded). Initially, we counted all burned and unburned trees within a $10 \mathrm{~m}$ radius of observation points spaced $50 \mathrm{~m}$ apart along 
the same two parallel $500 \mathrm{~m}$ transects within the 20 ha used for bird censuses. We also counted all flowering and fruiting trees within a $10 \mathrm{~m}$ radius of observation points spaced $50 \mathrm{~m}$ apart along those same $500 \mathrm{~m}$ transects.

The number of Byrsonima crassifolia fruiting trees and that of flowering Lafoensia pacari trees (the only tree species flowering and fruiting at that time) were censused only about 2 months post-fire in four $500 \mathrm{~m}$ transects: two in the burned area (within the 20 ha area) and two in a neighboring unburned area $1 \mathrm{~km}$ distant from the 20 ha area. We used the numbers for fruiting and flowering trees as indices of food resource. Since flowering plants attract insects, and insects attract insectivorous birds, this particular food availability index is probably valid for both frugivorous and insectivorous birds.

\section{Statistical analysis}

Because of the difference in techniques used to survey birds and plants, several statistical tests were used to investigate the effects of fire on bird species composition. Tests were conducted to detect changes in bird community composition both two months pre-fire and two months post-fire. We constructed a quantitative data matrix which represented 29 species captured in the mist nets two months before, and two months after the fire. Differences in bird species composition in sample units pre- and post-fire were described by semistrong hybrid multidimensional scaling (MDS) of the PATN program (Belbin, 1992) using the BrayCurtis dissimilarity measure. The Bray-Curtis index is calculated according to the formula:

$$
\mathrm{D}=\mathrm{S}\left|\mathrm{D}_{\mathrm{ik}}-\mathrm{D}_{\mathrm{jk}}\right| / \mathrm{S}\left\{\mathrm{D}_{\mathrm{ik}}-\mathrm{D}_{\mathrm{jk}}\right\}
$$

where: $\mathrm{D}_{\mathrm{ik}}=$ the data value for the $\mathrm{i}^{\text {th }}$ row and $\mathrm{k}^{\text {th }}$ column of the data matrix; $D_{j k}=$ the data value for the $j^{\text {th }}$ row and $k^{\text {th }}$ column of the data matrix.

This index has been recommended for use in bird-community and ecological studies (Minchin, 1987; MacNally, 1994). The MDS was used to generate a single ordination of sites, within the periods before and after fire, based on the BrayCurtis distance matrix. The same methods were used to compare bird community composition at a larger spatial scale (2000 ha). Multivariate analysis of variance (Manova), available in Systat 8.0 (Wilkinson, 1998), was used to test whether there were significant differences in bird community composition in the periods before and after fire. This analysis was performed for each spatial scale separately. Score values (dimension 1 or MDS1, and dimension 2 or MDS2) resulting from the MDS ordination were used together as dependent variables in each Manova model. Data on vegetation was used to test whether bird species richness or abundance was related to the number of unburned and burned trees or the number of flowering (Lafoensia pacari) and fruiting trees (Byrsonima crassifolia).

A posteriori Pillai-Trace test was used to verify whether MANOVA would reveal significant differences among periods pre and post-fire of small and large spatial scale. The Pillai-Trace statistics has been shown to be less sensitive to deviations from assumptions than other multivariate statistics (Johnson \& Field 1993, Olson 1976).

\section{RESULTS}

The most common tree species in the 20 ha area were Lafoensia pacari (26.7\% of all individuals in the ten $10 \times 10 \mathrm{~m}$ plots). Qualea grandiflora (17.8\%), Byrsonima crassifolia (13.3\%), B. coccolobifolia (11.1\%), Salvertia convallariodora (6.7\%), and Pouteria ramiflora (4.4\%) accounted for most of the other individuals. The same six species have also been found to be abundant in most of the peninsula. However, birds generally only eat fruits of the two species of Byrsonima (RC, unpubl. obs).

\section{Effects of fire on vegetation}

The numbers for unburned and burned trees were not significantly related to bird species richness (multiple regression analysis, partial regression, burned trees, $\mathrm{T}=-0.728, \mathrm{n}=22$, $\mathrm{p}=0.476$; partial regression, unburned trees, $\mathrm{T}=0.783, \mathrm{n}=22, \mathrm{p}=0.443$ ) nor to bird abundance (partial regression, burned trees, $\mathrm{T}=-0.857$; $\mathrm{n}=22, \mathrm{p}=0.402$; partial regression, unburned trees, $\mathrm{T}=0.739, \mathrm{n}=22, \mathrm{p}=0.469$ ). Data on birds and on burned and unburned trees used in these analyses are presented in Appendix 1.

Two months after the fire neither the number of flowering trees (Lafoensia pacari) nor the number of fruiting $B$. crassifolia trees within the burned area were significantly related to either bird species richness (multiple regression analysis, 
partial regression, flowering trees, $\mathrm{T}=0.615$, $\mathrm{n}=22, \mathrm{p}=0.546$; partial regression, fruiting trees, $\mathrm{T}=-1.032, \mathrm{n}=22, \mathrm{p}=0.315$ ) or bird abundance (partial regression, flowering trees, $\mathrm{T}=0.079$, $\mathrm{n}=22, \mathrm{p}=0.938$; partial regression, fruiting trees, $\mathrm{T}=-1.958, \mathrm{n}=22, \mathrm{p}=0.065$ ). Data on birds and trees used in these analyses are presented in Appendix 2.

In the unburned area, the abundances of flowering and fruiting trees were significantly correlated; therefore, they were analyzed in separate simple regression models. The results follow: the number for flowering trees (Lafoensia pacari) and that for fruiting $B$. crassifolia trees were not significantly related to bird species richness (simple linear regression: flowering trees, $\mathrm{r}^{2}=0.045, \mathrm{n}=22$, $\mathrm{p}=0.345$; simple linear regression: fruiting trees, $\left.\mathrm{r}^{2}=0.151, \mathrm{n}=22, \mathrm{p}=0.074\right)$. The relationships between numbers for flowering and fruiting trees were also not significantly related to bird abundance (simple linear regression: flowering trees, $\mathrm{r}^{2}=0.015, \mathrm{n}=22, \mathrm{p}=0.582$; fruiting trees, $\left.r^{2}=0.086, n=22, p=0.184\right)$.

\section{Effects of fire on bird community composition}

At the small (20 ha) spatial scale of this study, the MDS suggests that the bird species composition based on the mist-net data captured two months post-fire is very different from the bird community composition two months pre-fire (Table 1, Fig. 1). The ordination of the sample units in 2 dimensions by MDS indicated highly significant differences between the periods two months before and two months after the fire (Manova, Pillai Trace $=0.782 ; p=0.005)$. Direct ordination of bird species along the axis that separated burned from unburned plots (orthogonal to the line in Fig. 1) indicated that most species showed strong responses to the fire (Table 1). Two species (Elaenia flavogaster and Elaenia cristata) showed consistent changes associated with passage of fire. Thraupis episcopus occurred mostly in the burned

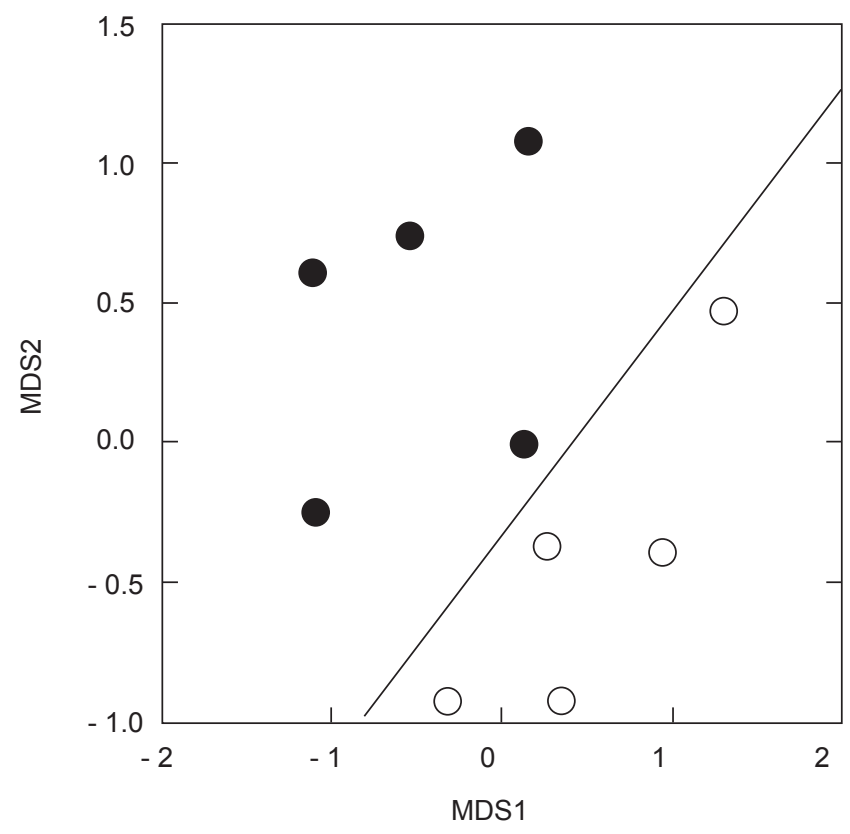

Fig. 1 - Results of multidimensional scaling (MDS) used to generate ordination of sites of bird capture both pre- and post-fire (two months before fire: open circles; two months after fire: filled circles; see methods) based on the Bray-Curtis distance matrix (see methods). Bird community composition changed after the fire. Each circle represents a sampling unit consisting of 20 mist nets (one net line) at a small spatial scale (20 ha). In this figure the closest the circles the more similarity exist among the bird communities. 


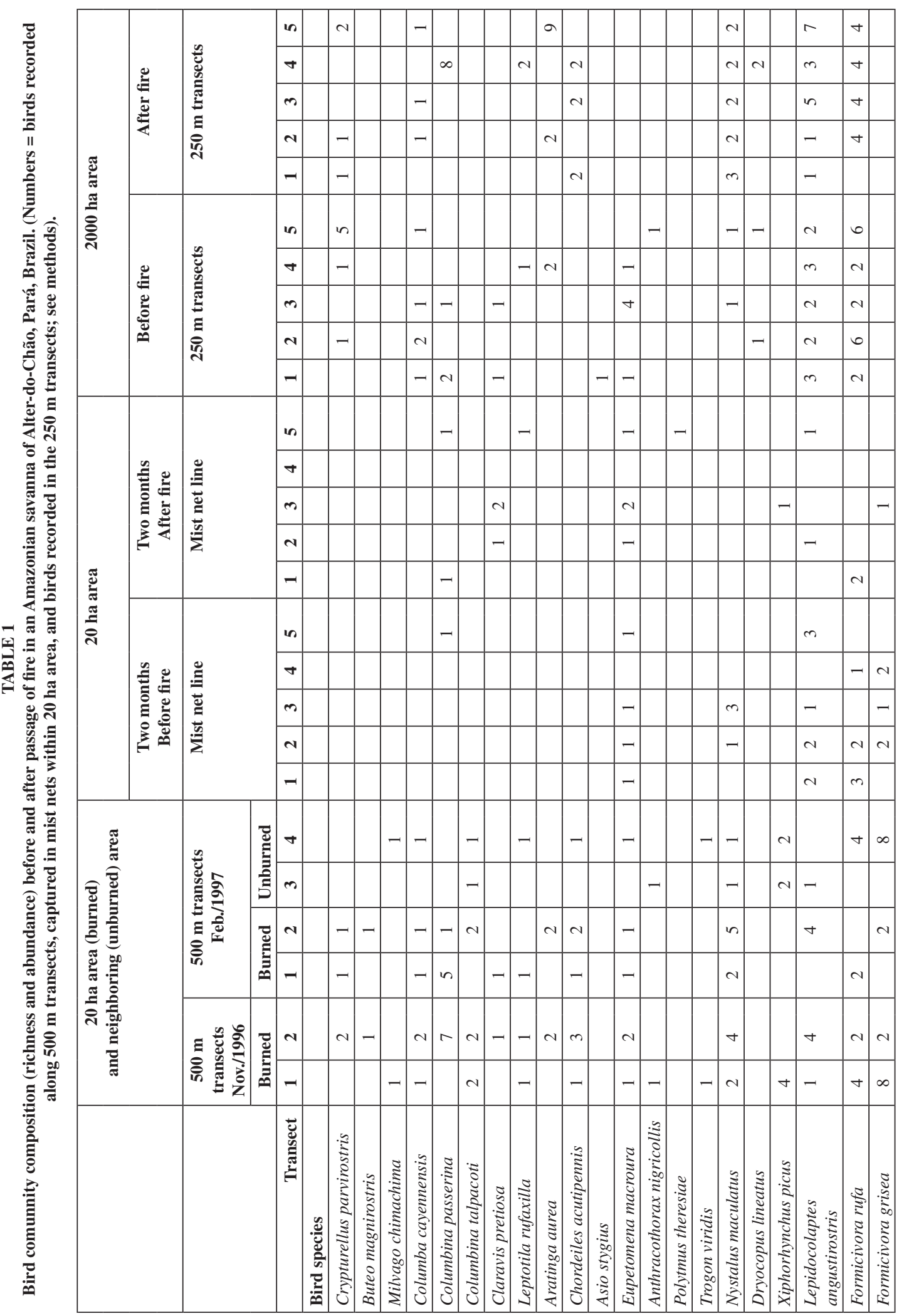




\begin{tabular}{|c|c|c|c|c|c|c|c|c|c|c|c|c|c|c|c|c|c|c|c|c|c|c|c|c|c|c|c|c|c|c|c|c|c|}
\hline in & & & & & $m$ & & & & & -1 & & & $\nabla$ & 으 & & & $r$ & & & & & & & & & & $n$ & & & & & & \\
\hline$\nabla$ & & & & & $N$ & & & & -0 & $m$ & & & - & 이 & & & & & & $N$ & & & & $m$ & & & $r$ & & & & & & \\
\hline$m$ & & & & & - & & & & $N$ & -1 & & & $\nabla$ & in & & & \pm & 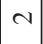 & & - & & - & & & & & $\nabla$ & & & & & & \\
\hline 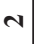 & & & & & & & & & & $N$ & & & $\nabla$ & 0 & & & $r$ & $N$ & & & & - & & & & & & & & & & & \\
\hline-1 & & & & & $m$ & & & & $m-$ & -1 & & & - & $\simeq$ & & & $m$ & $N$ & & & - & & & - & & & $N$ & & & & & & 으 \\
\hline in & & & & & & & & & $\mathrm{N}$ & $N$ & & & $\nabla$ & $r$ & - & & $\nabla$ & & & & & - & & & & & $N$ & $N$ & & & - & & $N$ \\
\hline$\nabla$ & & & & & & & & & & $N$ & & & $\sim$ & $m$ & & & $\sim$ & & & & - & & & & & & & & & & & & 0 \\
\hline$m$ & & & & & & & & & & & & & & $m$ & & & $n$ & - & & & & $\sim$ & & & & & $N$ & & & & & & $N$ \\
\hline$N$ & & & & & & & & & -4 & $n$ & & & - & in & $N$ & & 0 & & $N$ & & - & - & & & & & $N$ & & & & & & $N$ \\
\hline-1 & & & & $m$ & & & & & -0 & $m$ & & & & 0 & - & & 0 & $N$ & & & - & & & & & & & & & $N$ & $\sim$ & & $N$ \\
\hline in & & & - & & & & & & - & & & & $N$ & 0 & & & & & & & & & & & & & $N$ & - & & & - & $a$ & - \\
\hline$\nabla$ & & & & & & & & & & & & & - & $m$ & $n$ & & $\sim$ & - & & & & & & & & & $N$ & & & & & -1 & $v$ \\
\hline$m$ & & & & & & & & & & & & & $m$ & in & $N$ & & & - & & & & & & & & & & $N$ & & & & & - \\
\hline$N$ & & - & & - & & & & & & & & & $r$ & -1 & - & & & & & - & & & & - & & & $N$ & - & - & & & & - \\
\hline-1 & & & & & & & & & $N$ & & & & $\sim$ & 0 & - & & & & & - & & & & & & & $m$ & - & & & - & & \\
\hline in & & & & & & & & & & & & - & & $m$ & $n$ & & & & & & & & & & & & $\sim$ & & - & & & & - \\
\hline$\nabla$ & & & & & & & & & & $m$ & & & & & & & & & & & & & & & & & - & & & & & & $N$ \\
\hline$m$ & & & & & & & & & & $m$ & & & & & $m$ & & & - & & & & & & & & & - & & & & $N$ & & - \\
\hline$N$ & & & & & & & & & $N$ & -1 & & & - & & & & & & & & & & & & & & - & & & & & & - \\
\hline-1 & & & & & & & & & & & & & & $N$ & & & & & & & - & & & & & & & & & & & & - \\
\hline$\nabla$ & & & & - & - & $N$ & 0 & & $\mathrm{~N}$ & -1 & - & & $\sim$ & $N$ & $r$ & - & & & & $N$ & $N$ & & $N$ & & & & $\nabla$ & & & $N$ & $N$ & & \\
\hline$m$ & & & & $m$ & - & t & - & & $N$ & & & & $\sim$ & $a$ & $m$ & & 0 & & & $N$ & & & - & - & $\sim$ & - & $r$ & $N$ & -1 & $N$ & $\sim$ & & - \\
\hline$N$ & & & & $\nabla$ & $\sim$ & $v$ & & & -7 & -1 & & & - & $\cong$ & $N$ & & $\nabla$ & - & & - & & & - & $m$ & & & - & + & & & & $N$ & $m$ \\
\hline-1 & & & & $m$ & $N$ & - & & & -7 & -1 & & & - & 의 & $N$ & & $\nabla$ & & & $N$ & $N$ & - & - & & & - & $N$ & $N$ & & & $\nabla$ & & $m$ \\
\hline$v$ & & & & $r$ & | & $m$ & & & $N o$ & $N$ & & & $\sim$ & $\vec{\sim}$ & + & & $\infty$ & - & & $m$ & - & - & $N$ & $m$ & & - & $m$ & $n$ & & & $m$ & $N$ & in \\
\hline-1 & & & & $m$ & 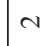 & | & m & & $m a$ & $N$ & -1 & & $\nabla$ & 0 & 의 & - & 0 & & & $\nabla$ & 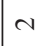 & & $m$ & - & 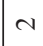 & -1 & $=$ & $N$ & -1 & $\nabla$ & $\nabla$ & & - \\
\hline 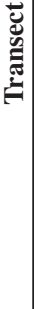 & 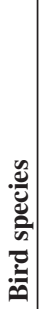 & 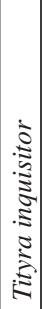 & 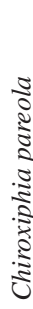 & 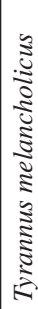 & 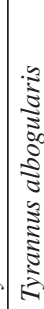 & 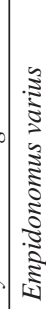 & 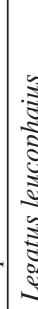 & 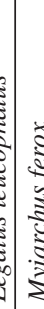 & 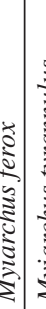 & 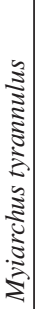 & 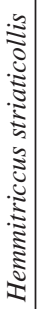 & 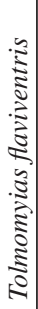 & 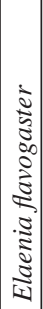 & 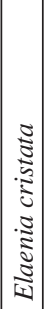 & 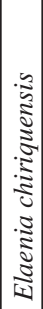 & 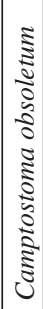 & 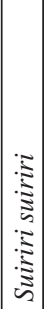 & 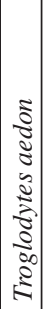 & 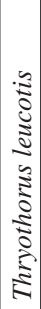 & 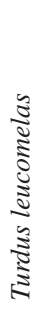 & 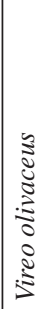 & 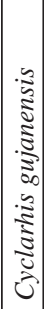 & 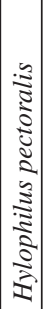 & 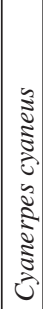 & 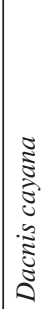 & 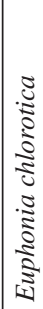 & 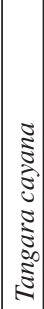 & 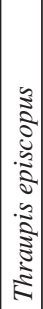 & 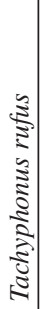 & 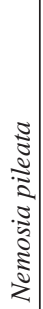 & 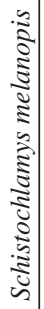 & 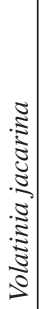 & 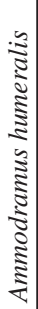 \\
\hline
\end{tabular}


areas whereas at the small spatial scale Myiarchus tyrannulus was found only pre-fire (Table 1).

At the large spatial scale (2000 ha) the results confirmed patterns found for bird community composition at the small scale (Table 1). The ordination of the sample units by MDS also showed significant differences in bird community composition between the periods before and two months after the passage of fire (Manova, Pillai Trace $=0.744 ; \mathrm{p}=0.008$ ). Differences between time periods were captured principally along MDS2 (Fig. 2). Some bird species such as Tyrannus albogularis, Chordeiles acutipennis, Aratinga aurea, Nystalus maculatus, Elaenia cristata, and Lepidocolaptes angustirostris were more abundant post-fire. Pre-fire, Vireo olivaceus, Cyclarhis gujanensis, Eupetomena macroura, and Elaenia chiriquensis had been more common (Table 1).

\section{DISCUSSION}

Since bird community composition before the fire was significantly different from that after the fire both at a small (within a 20 ha area) and large spatial scale (2000 ha). The results of this study strongly suggests direct post-fire effects on bird community composition and structure.

While some of the changes attributed to fire may be due to normal seasonal changes in community composition, during the study the area was affected by an El Ninõ climatic event. The result was weakened seasonal effects in a climate already experiencing little seasonal alteration, with apparently no strong seasonal repercussions on species composition, as far as we have noted after years of observing local birds.

In the 20 ha area, the abundance of some mainly insectivorous bird species such as

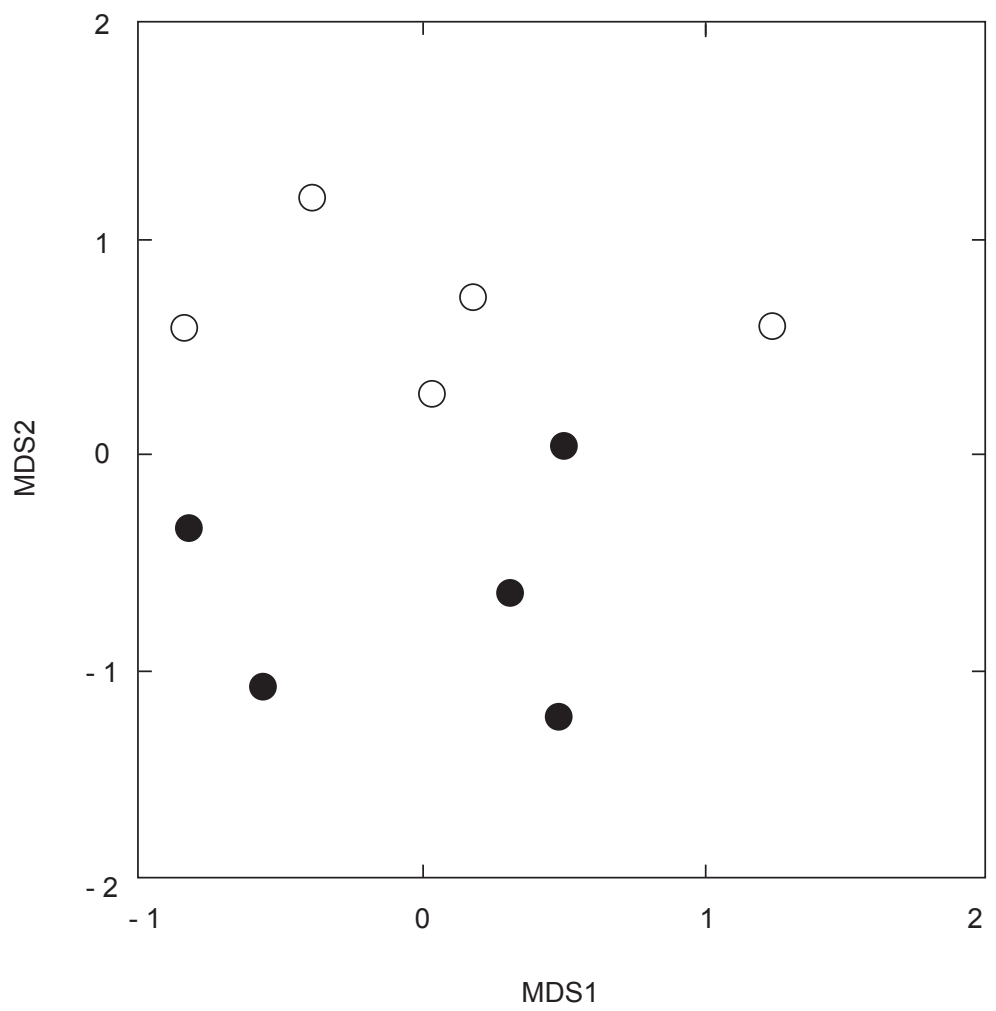

Fig. 2 - Results of a multidimensional scaling (MDS) used to generate ordination of sites in which birds were recorded preand post-fire (two weeks before fire: open circles; two months after fire: filled circles; see methods) based on the Bray-Curtis distance matrix (see methods). Bird community composition changed after the fire. Each circle represents a sampling unit, i.e., a 3.75 ha plot (two $250 \mathrm{~m}$ transects within the plot) at a large spatial scale (2000 ha). In this figure the closest the circles the more similarity exist among the bird communities. 
Myiarchus tyrannulus, Formicivora rufa (this species changed little at a large spatial scale), and F. grisea decreased, while species such as Thraupis episcopus increased post-fire (Table 1).

At the small spatial scale some canopy nectarivores, e.g., the hummingbird Eupetomena macroura and the canopy seed and fruit eater Tangara cayana were apparently not affected by the fire event, while at a large spatial scale, Tangara cayana tended to increase in abundance whereas Eupetomena macroura disappeared from the burned areas (Table 1). This may be because most tall trees did not burned, although we recorded canopy burning at up to $10 \mathrm{~m}$ for several tree species in the area (Bowdichia virgilioides, Byrsonima crassifolia, Salvertia convallariodora, Himatanthus fallax, and Pouteria ramiflora). Results for some bird species, such as Tangara, that increased in abundance seem to be habitatindependent. A recent study found that arboreal granivorous birds were more abundant after a ground fire passed in a forest area on the left margin of the Tapajós River (Barlow et al., 2002).

At the large spatial scale bird species such as Tyrannus albogularis, Chordeiles acutipennis, Aratinga aurea, Nystalus maculatus, Elaenia cristata, and Lepidocolaptes angustirostris were more abundant post-fire passage (Table 1). The apparent increase in Ammodramus humeralis occurred only in one area and may have been due to the drastically reduced cover and, therefore, greater visibility in that area of this grounddwelling species. This may also be partially true for such arboreal frugivorous birds as Aratinga aurea, which increased regionally in abundance post-fire (Table 1).

At the small spatial scale, some birds, e.g., Nystalus maculatus, that forage and build their nests in burrows or on the soil surface showed reduced densities and some disappeared from the burned areas (Table 1). However, at the large spatial scale this species increased in abundance postfire (Table 1). This may be because they follow invertebrate colonization on the newly sprouting plants.

Ground-walking bird species may use unburned forest edges as refuges from fire (R.C., pers. obs.). Even birds with limited flight capacity, e.g., such as tinamous, were seen flying over $2 \mathrm{~m}$ high flames (R.C., pers. obs.). In the savanna itself, unburned areas are available for use as nesting sites for species such as Nystalus maculatus, which nests underground in a tunnel; Aratinga aurea, which nests in termite nests; and woodcreepers, which nests in tree holes, may escape fire damage (R.C., unpubl. data). As an example, abundance of Myiarchus ferox changed little post-fire. In contrast, Myiarchus tyrannulus, which use tree holes, disappeared from the 20 ha area, but there was little effect on their abundance at the 2000 ha scale. In addition, an active nest with two nestlings of Myiarchus tyrannulus was found in a tree hole $2 \mathrm{~m}$ above the ground in November 1997 just a few days post-fire.

By way of comparison, in the heath vegetation of western Australia, only 59\% of adult female western thornbills attempted to nest in a post-fire season. At least two bird species (a scrubwren and a honeyeater) did not nest for two years post-fire, with another species (Acanthiza apicalis) not nesting for up to five years (Brooker \& Rowley, 1991). Fire was also found to decrease bird species richness in coastal sage scrub (Stanton, 1986) and in the savannas of the central plateau of Brazil (Cavalcanti, 1988). In a site near Brasília, banded birds were tracked pre- and post-fire, and only three species (white-banded tanager, narrow-billed woodcreeper, and suiriri flycatcher) were recorded post-fire (Cavalcanti, 1988; Alves \& Cavalcanti, 1996).

In a lizard community in Brasília, Araujo et al. (1996) found that less than a third of the six local lizard species were fire-tolerant and colonized unoccupied sites after burning. The authors suggested that fire is an important factor in maintaining local species richness through gap colonization by resident species. On the other hand, they found that burning large areas drastically reduced species richness. Although we believe this may occur with some bird species, the same cannot be said for all community members because of different degrees of fire tolerance in some bird species and possible flight to neighboring unburned areas. Since the majority of insectivorous bird species in the area depend on the vegetation for perching and foraging, fire decreases habitat quality for permanent resident bird species as it dramatically decreases vegetational structural heterogeneity and, therefore, foraging opportunities (Stanton, 1986; Cintra, 1997; Barlow et al., 2002). 
In a forested area located on the other side of the Tapajós River, Barlow et al. (2002) found that insectivorous birds from different guilds (such as ant followers, dead-leaf gleaners, and arboreal sallying insectivores) were the most negatively affected after fire in the forest.

An indirect effect of fire on bird community composition may also result from its negative impact on the invertebrate community. Fire can reduce significantly the abundance of some dung beetle (Scarabaeidae) species (Lousada et al., 1996) and some arboreal ant species (Cephalotes, Crematogaster, Azteca, Zacryptocerus, and Pseudomyrmex) (Naves, 1996). Although birds do not usually feed on ants, the distribution and abundance of many other arthropods (spiders, caterpillars, butterflies, beetles) can be affected negatively by ant presence and abundance (Halaj et al., 1997).

The timing of fires is also significant. Because most fire events start in the middle of the dry season when the majority of bird species begin breeding (Sanaiotti \& Cintra, 2001), bird population recruitment could be affected negatively by a reduction both in safe nesting sites and food supplies (Howe \& De Steven, 1979; Sanaiotti \& Magnusson, 1995). However, this possibility in the area studied has yet to be investigated.

Unfortunately, forest burning is also increasing at high rates within large areas immediately surrounding Alter-do-Chão. Since fire is an annual occurrence there, and is becoming frequent in the Amazon as a whole, it could be affecting the distribution and abundance of many bird species. However, this was a short-term study, and analyzing all the direct and indirect effects of fire on the savanna bird community will require further study. Without a long-term study, we cannot even account for many bird species post-fire, and whether they return to the same sites or seek refuge in neighboring habitats. However, in our research on bird longevity at the same site (the 20 ha area) we have recaptured birds, some as old as fourteen years, of several species, indicating that they remain in the area (Sanaiotti \& Cintra, 2006, unp. manuscript).

Acknowledgements - We thank the people from the village of Alter do Chão; Braulio Sardinha, Silvina Sardinha, Evaldo C. Ferreira, Williames S. da Costa, Welton S. da Costa, and Laudeco da Costa, for their logistical support, field assistance, and friendship; and SUDAM for logistical support. Glaúcio Belém da Silva (INPA) helped with the figures. We thank an anonymous referee, Peter Peterman, and Anne Zillikens for suggestions that improved the manuscript. Bill Magnusson helped us with part of the statistical analysis. We thank the Centro de Estudos de Migrações de Aves (CEMAVE)/Instituto Brasileiro do Meio Ambiente (IBAMA) for supplying us with the rings used to tag birds. This study was supported by the Instituto Nacional de Pesquisas da Amazônia (INPA). We dedicate this study to the memory of Nilcivan C. Ferreira.

\section{REFERENCES}

ALVES, M. A. S. \& CAVAlCANTI, R., 1996, Sentinel behavior, seasonality, and the structure of bird flocks in a Brazilian Savanna. Ornitol. Neot., 7: 43-51.

ARAUJO, A. F. B, COSTA, E. M. M, OLIVEIRA, R. F., FERRARI, K., SIMON, M. F. \& PIRES-JUNIOR, O. R., 1996, Efeitos de queimadas na fauna de lagartos do Distrito Federal. pp.148-160. In: Anais do Simpósio Impacto das queimadas sobre os ecossistemas e mudanças Globais. Brasília.

BARBOSA, R. I. \& FEARNSIDE, P. M., 1999, Incêndios na Amazônia Brasileira: Estimativa da emissão de gases do efeito estufa pela queima de diferentes ecossistemas de Roraima na passagem do evento "El Niño". Acta Amaz., $29: 513-534$.

BARLOW, J., HAUGAASEN, T. \& PERES, C. A., 2002, Effects of ground fires on understorey bird assemblages in Amazonian forests. Biol. Conserv., 105: 157-169.

BELBIN, I., 1992, PATN: Pattern analysis package. CSIRO, Canberra.

BROOKER, M. \& ROWLEY, G., 1991, Impact of wildfire on the nesting behavior of birds in heathland. Wild. Res., 18: 249-263.

CAVALCANTI, R. B., 1988, Conservation of birds in the Cerrado of Central Brazil. pp. 59-66. In: Ecology and Conservation of Grassland birds, Goriup, P.D. (ed.), ICBP Technical Publication 7. Norfolk, England.

CAVALVANTI, R. B. \& ALVES, M.A.S., 1997, Effects of fire on savanna birds in Central Brazil. Ornitol. Neot., 8: 85-87.

CAVALCANTI, R. B. \& PIMENTEL, T. M., 1988, Shiny Cowbird parasitism in Central Brazil. Condor, 90: 40-43.

CINTRA, R., 1988, Reproductive ecology of the Ruddy GroundDove on the Central Plateau of Brazil. Wilson. Bull., 100: 443-457.

CINTRA, R., 1997, Spatial distribution and foraging tactics of tyrant flycatchers in two habitats in the Brazilian Amazon. Stud. Neot. Fauna \& Environment, 32 :17-27.

CINTRA, R., ALVES, M. A. S. \& CAVALCANTI, R., 1990, Dieta da rolinha Columbina talpacoti (Aves, Columbidae) no Brasil Central - Comparação entre sexos e idades. Rev. Bras. Biol., 50 :469-473.

COUTINHO, L. M., 1982, Ecological effects of fire in Brazilian Cerrado, pp.273-291. In: B.J. Huntley \& B.H. Walker (eds.), Ecological Studies 42, Ecology of Tropical Savannas. Springer- Verlag, Berlin. 
GIBBONS, D. W., HILL, D. \& SUTHERLAND, W L., 1996, Birds. In: Ecological census techniques. W.J. Sutherland (ed.), Cambridge University Press, Cambridge.

HALAJ, J., ROSS, D. W. \& MOLDEDNKE, A. R., 1997, Negative effects of ant foraging on spiders in Douglas-fir canopies. Oecologia, 109: 313-322.

HOWE, H. F. \& De STEVEN, D., 1979, Fruit production, migrant birds visitation and seed dispersal of Guarea glabra in Panama. Oecologia, 39:185-196.

HUBER, O.,1982, Significance of savanna vegetation in the Amazon territory of Venezuela. pp. 221-224. In: Prance G. T. (ed.), Biological Diversification in the Tropics, Columbia University Press, New York.

JOHNSON, C. R. \& FIELD, C. C., 1993, Using fixed-effects model multivariate analysis of variance in marine biology and ecology. Oceanography and Marine Biology Annual Review, 31: 177-221.

LOUSADA, J. N. C., SCHIFFER, G. \& VAZ DE MELO, F. Z., 1996, Efeitos do fogo sobre a estrutura da comunidade de Scarabaeidae (Insecta, Coleoptera) na Restinga da Ilha de Guiriri-ES., pp. 161-169. In: Anais do Simpósio Impacto das queimadas sobre os ecossistemas e mudanças globais, Brasília, DF.

MACEDO, R., 2002, The Avifauna: Ecology, biogeography, and behavior. pp. 242-265. In: Paulo S. Oliveira \& Robert J. Marquis (eds.), The Cerrados of Brazil - Ecology and Natural History of a Neotropical Savanna. Columbia University Press, New York.

MACNALLY, R. C., 1994, On characterising foraging versatility, illustrated by using birds. Oikos, 69: 95-106.

MAGNUSSON, W. E., LIMA, A. P., FARIA, A. S., VICTORIA R. L. \& MARTINELLI, L. A., 2001, Size and carbon acquisition in lizards from Amazonian savanna: evidence from isotope analysis. Ecology, 82: 1772-1780.

MARINI, M. A., MOTTA-JUNIOR, J. C., VASCONCELOS, L. A. S. \& CAVALCANTI, R. B., 1997, Avian body masses from the Cerrado region of central Brazil. Ornitol. Neot., 8: 93-99.

MEYER DE SCHAUENSEE, R., 1970, A Guide to the Birds of South America. Reprinted by ICBP Panamerican section. Academy of Natural Sciences of Philadelphia, Philadelphia, $424 \mathrm{p}$.

MINCHIN, P. R., 1987, An evaluation of the relative robustness of techniques for ecological ordination. Vegetatio, 69: 89-107.

MIRANDA, I., 1993, Estrutura do estrato arbóreo do cerrado amazônico em Alter-do-Chão Pará, Brasil. Rev. Bras. Bot., 16: $143-150$.

MOSKOVITS, D. FITZPATRICK, J. W. \& WILLARD, D. E., 1985, Lista preliminar das aves da estação ecológica de Maracá, território de Roraima, Brasil, e áreas adjacentes. Pap. Avul. Zool. S. Paulo., 36 :51-68.

MYERS, N., MITTERMEIER, R. A., MITTERMEIER, C. G., FONSECA, G. A. B. \& KENT, J., 2000, Biodiversity hotspots for conservation priorities. Nature, 403: 853-858.
NAVES, M., 1996, Efeito do fogo na população de formigas (Hymenoptera-Formicidae) em Cerrado do Distrito federal, pp. 170-177. In: Anais do Simpósio Impacto das queimadas sobre os ecossistemas e mudanças globais, Brasília, DF.

NEGRET, A. J. \& NEGRET, R. A., 1981, As aves migratórias do Distrito Federal, Boletim Técnico 6. IBGE. Ministério da Agricultura. $64 \mathrm{p}$.

NEGRET, A. J., TAYLOR, J., SOARES, C. R., CAVALCANTI, R. B., JOHNSON, C., 1984, Aves da região geopolítica do Distrito Federal. Sema/ Minter. 21 p.

NOVAES, F. C., 1978, Ornitologia do Território do Amapá I. Mus. Par. Emílio Goeldi, Publ. Avul., 25., 121 p.

OLSON, C.L., 1976, On choosing a test statistic in multivariate analysis of variance, Psychological Bulletin, 83: 579-586.

PETERSON, D. L. \& PARKER, V. T., 1997, Ecological Scale. Columbia University Press, New York.

PRANCE, G. T. \& LOVEJOY, T. E., 1985, Key Environments: Amazonia. Pergamon Press, Oxford.

RIDGELY. R. \& TUDOR, G., 1994a, The Birds of South America, Vol. 1 (The oscine passerines), Univ. of Texas Press, Austin, Texas.

RIDGELY, R. \& TUDOR, G., 1994b, The Birds of South America, Vol. 2 (The suboscine passerines), Univ. of Texas Press, Austin, Texas.

RIKER, C. B. \& CHAPMAN, F. M., 1981, A list of birds observed at Santarem, Brazil. Auk, 8: 24-31.

SANAIOTTI, T. M. \& MAGNUSSON, W. E., 1995, Effects of annual fire on the production of fleshy fruits eaten by birds in a Brazilian Amazonian savanna. J. Trop. Ecol., 11: 53-65.

SANAIOTTI, T. M. \& CINTRA, R., 2001, Breeding and migrating birds in an Amazonian savanna. Stud. Neotrop. Fauna \& Environment, 36: 23-32.

SANAIOTTI, T. M. \& CINTRA, R. 2006. Longevity records for birds from a Savanna in eastern Brazilian Amazonia. (Unpubl. Manuscript).

SICK, H., 1985, Migrações de aves na América do Sul Continental. Pub.Técnica 2-Cemave, IBDF, Ministerio da Agricultura. Brasília, DF. 86 p.

SILVA, J. M. C., 1995, Birds of Cerrado Region, South America. Steenstrupia, 21: 69-92.

SILVA, J. M. C., OREN, D.C., ROMA, J. C. \& HENRIQUES, L. M. P., 1997, Composition and distribution patterns of the avifauna of an Amazonian upland savanna, Amapá, Brazil. Ornithol. Monog., 48: 743-762.

STANTON, P. A., 1986, Comparison of avifauna community dynamics of burned and unburned coastal sage scrub. Condor, 88: 285-289.

STOTZ, D. F., 1997, Levantamento preliminar da avifauna em Roraima. pp. 581-608. In: Barbosa R. J, Ferreira E. J. G., \& Castellõn E. G (eds.), Homem, ambiente e ecologia no Estado de Roraima, INPA Manaus.

WILKINSON, L., 1998, Systat: the system for Statistics. Systat, SPSS Inc. Evanston, IL. 
APPENDIX 1

Data of birds and trees recorded in each observation point (each $50 \mathrm{~m}$ ) along the two $500 \mathrm{~m}$ transects in the burned area of 20 ha area, in November 1996, in an Amazonian Savanna of Alter-do-Chão, Pará.

\begin{tabular}{|c|c|c|c|c|c|}
\hline $\begin{array}{c}500 \mathrm{~m} \\
\text { Transects }\end{array}$ & $\begin{array}{c}\text { Observation } \\
\text { points }(\mathbf{m})\end{array}$ & Bird richness & Bird abundance & $\begin{array}{c}\text { Number of } \\
\text { burned trees }\end{array}$ & $\begin{array}{c}\text { Number of } \\
\text { unburned trees }\end{array}$ \\
\hline 1 & 0 & 5 & 6 & 4 & 13 \\
\hline 1 & 50 & 3 & 5 & 4 & 10 \\
\hline 1 & 10 & 6 & 7 & 4 & 7 \\
\hline 1 & 150 & 3 & 4 & 3 & 9 \\
\hline 1 & 200 & 5 & 7 & 4 & 10 \\
\hline 1 & 250 & 6 & 6 & 1 & 14 \\
\hline 1 & 300 & 3 & 4 & 2 & 15 \\
\hline 1 & 350 & 2 & 3 & 3 & 13 \\
\hline 1 & 400 & 2 & 3 & 4 & 12 \\
\hline 1 & 450 & 6 & 10 & 4 & 17 \\
\hline 1 & 500 & 3 & 4 & 6 & 13 \\
\hline 2 & 0 & 3 & 5 & 21 & 6 \\
\hline 2 & 50 & 3 & 3 & 15 & 7 \\
\hline 2 & 100 & 4 & 4 & 8 & 14 \\
\hline 2 & 150 & 2 & 2 & 13 & 5 \\
\hline 2 & 200 & 3 & 4 & 15 & 4 \\
\hline 2 & 250 & 2 & 2 & 19 & 5 \\
\hline 2 & 300 & 4 & 4 & 18 & 10 \\
\hline 2 & 350 & 3 & 5 & 13 & 3 \\
\hline 2 & 400 & 3 & 4 & 7 & 9 \\
\hline 2 & 450 & 3 & 4 & 6 & 13 \\
\hline 2 & 500 & 4 & 6 & 4 & 14 \\
\hline
\end{tabular}




\begin{tabular}{|c|c|c|c|c|c|c|c|c|c|c|c|c|c|c|c|c|c|c|c|c|c|c|c|}
\hline & 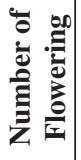 & 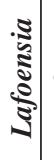 & $\sim$ & $m$ & $N$ & - & 0 & $\sim$ & -1 & $m$ & $m$ & $N$ & -10 & $\mathrm{~N}$ & 0 & 0 & 0 & 0.1 & -10 & $v-$ & 0 & $N$ & $m$ \\
\hline & 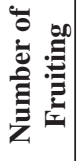 & 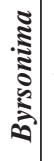 & - & $r$ & 0 & $\nabla$ & $N$ & $\sim$ & $\sim$ & -1 & $n$ & $N 4$ & $n$ & $m-$ & - & 0 & - & 0 & $\mathrm{~N} / \mathrm{T}$ & + & 0 & 0 & $N$ \\
\hline 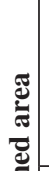 & 를 & & $m$ & $m$ & 0 & $r$ & $n$ & $m$ & 0 & $\infty$ & $\infty$ & 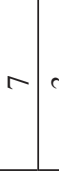 & $n$ & N & $m$ & 0 & 0 & 0 & $n$ & $+\infty$ & $\infty$ & $a$ & $N$ \\
\hline 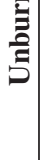 & D. & & $N$ & $\mathrm{~N}$ & $\nabla$ & $n$ & $m$ & $m$ & $\nabla$ & $n$ & $n$ & $\forall \mid$ & $m \mid c$ & $\mathrm{~N} / \mathrm{C}$ & $m$. & $n$ & $\nabla$ & $n \mid c$ & $m \mid c$ & 0 & in & $r$ & $N$ \\
\hline & 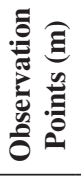 & & 0 & 으 & 으 & $\stackrel{ }{n}$ & ঠ্ণ & 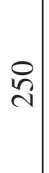 & ৪্ & $\begin{array}{c}\text { in } \\
\text { m. }\end{array}$ & ৪) & ำ & $\begin{array}{l}8 \\
i n\end{array}$ & 0.8 & 으 & 8 & 욕 & ઠ્ટ & 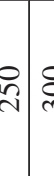 & $\stackrel{n}{n}$ & 8 & ஜூ & 8 \\
\hline & 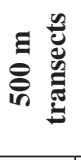 & & $m$ & $m$ & $m$ & $m$ & $m$ & $m$ & $m$ & $m$ & $m$ & $m \mid c$ & $m$ & $\nabla$ & $\nabla$ & $\nabla$ & $\nabla$ & $\nabla \mid$ & $\forall \mid$ & $+\quad \forall$ & $\mid+$ & $\forall$ & $\nabla$ \\
\hline & 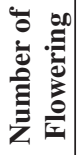 & 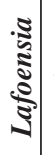 & -1 & -1 & $m$ & $N$ & $m$ & -1 & $\nabla$ & N & -1 & -10 & $m-$ & -10 & $\mathrm{~N}$ & $-c$ & $N$ & 0 & -10 & 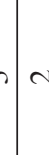 & - & $N$ & $m$ \\
\hline & 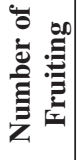 & 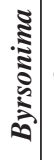 & $m$ & N & -1 & $\nabla$ & $n$ & 6 & $m$ & $\nabla$ & 0 & $n$ & $n$ & $-1-$ & $\nabla$ & $\mathrm{N}$ & $m$ & $n$ & $\forall \mid \alpha$ & 0 & in & - & - \\
\hline 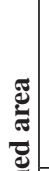 & 串 & & $r$ & $m$ & in & $\infty$ & $n$ & 0 & $r$ & $m$ & $m$ & $\infty$ & $m$ & a 1 & $m$ & 0 & $\nabla$ & $n$ & $\begin{array}{lll}6 & 1\end{array}$ & -1 & in & 6 & 으 \\
\hline 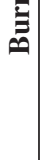 & D. & & $n$ & $N$ & $m$ & 0 & $\nabla$ & $n$ & $n$ & $N$ & $m$ & $n$ & $m$ & $n \mid c$ & $m$ & $\nabla$ & $\nabla$ & $\nabla$ & $n$ & 0 & $m$ & $\nabla$ & $r$ \\
\hline & 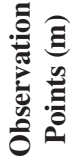 & & 0 & $\stackrel{n}{n}$ & 으 & $\stackrel{ }{\stackrel{n}{n}}$ & $\underset{\sim}{~}$ & 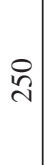 & ৪্ল & 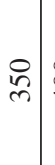 & \& & $\stackrel{8}{7}$ & $\begin{array}{l}8 \\
\stackrel{n}{n}\end{array}$ & 0 & 오 & 8 & $\stackrel{2}{2}$ & 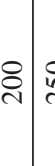 & 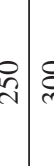 & 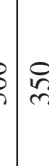 & 8 & $\stackrel{\circ}{7}$ & 8 \\
\hline & 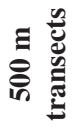 & & -1 & - & - & - & - & - & -1 & -1 & -1 & - & - & $\mathrm{N} \mid \mathrm{C}$ & $\mathrm{N}$ & $N$ & $N$ & N & $\mathrm{N} / \mathrm{c}$ & $v \curvearrowright$ & $N$ & $N$ & $\mathrm{~N}$ \\
\hline
\end{tabular}

